\title{
Studies in the liverwort genus Fossombronia (Metzgeriales) from southern Africa. 10. Three new species from Northern and Western Cape
}

\author{
S.M. PEROLD*
}

Keywords: Fossombronia Raddi, F. hyalorhiza Perold, F. marindae Perold, F. monticola Perold, Hepaticae, Metzgeriales, Northern Cape, southern Africa, Western Cape

\section{ABSTRACT}

Three new species of Fossombronia from the winter rainfall area of the Northern and Western Cape are described: $F$ hyalorhiza, which has colourless rhizoids and is fairly widespread, but not common; $F$ marindae, which has purple rhizoids, very attractive, highly ornamented spores and is so far known from a single locality only and $F$. monticola, which also has purple rhizoids, with spores irregularly ridged, often partly areolate, and is quite common but fairly variable.

\section{Fossombronia hyalorhiza Perold, sp. nov.}

Plantae repentes, caulibus viridibus, nucleo centrali purpureo. Rhizoidea hyalina. Folia undulata, saepe incisa vel lobata, interdum forma valde variabili. Dioicae. Antheridia in plantis masculis bracteis obtecta. Pseudo. perianthium cupulatum; ore undulato, cum \pm 11 prominentiis irregularibus. Sporae 40.0-57.5 $\mu \mathrm{m}$ diametro, interdum 55.0-67.5 $\mu \mathrm{m}$; superficie distali cum 6-8(-9) cristis irregularibus, rectis vel curvatis, brevibus vel longibus. Elateres $100.0-227.5 \times 7.5-10.0 \mu \mathrm{m}$, omnino ter spirales vel solum medio, extremitatibus bis spirales, rarissime quater vel quinquiens spirales.

TYPE.-Northern Cape, 3219 (Wuppertal): Skurweberge, on road from Ceres to Citrusdal, $\mathrm{N}$ of Op-dieBerg, along turnoff to Boplaas; slightly beyond hiking trail, near Sandrivier; below seep, at rocks with mosses, (-AB), S.M. Perold 3867 (PRE, holo.).

Plants medium-sized to fairly large, gregarious, mostly growing together with mosses, green, but leaves soon dying and turning translucent, sometimes marginally purple, occasionally with 3 or 4 rows of purple cells at base or sparsely blotched with purple throughout, shoots often simple or once-furcate, rarely with short lateral branches or buds near base, frequently arising from tuberous apex of old stem, which is up to $500 \times 600 \mu \mathrm{m}$. flanked by small, often purple leaves (Figure $1 \mathrm{~K}$ ), tapering proximally and $3-5 \mathrm{~mm}$ long; male plants $5-8 \times \pm$ $3.2 \mathrm{~mm}, \pm 1.6 \mathrm{~mm}$ high; female plants larger, $10-15 \times \pm$ $3.7 \mathrm{~mm}, \pm 2 \mathrm{~mm}$ high. Stems prostrate, sometimes arching, distally fleshy, proximally tapering, dorsally green. ventrally purple, in cross section with outer layers of lateral and ventral cells green, core \pm central or ventrally displaced, purple, persistent in older shoots, 'tailing off' in young ones, plano-convex to slightly biconvex, in male plants at apex (Figure $1 \mathrm{~N})$ up to $550 \mu \mathrm{m}$ (14 cell rows) high, $\pm 600 \mu \mathrm{m}$ wide, at base (Figure $1 \mathrm{O}$ ) $\pm 300 \times$ $360 \mu \mathrm{m}$; in female plants at apex (Figure $1 \mathrm{P}$ ) up to 530 $\mu \mathrm{m}$ ( 14 cell rows) high, $\pm 620 \mu \mathrm{m}$ wide, at base (Figure 1Q) $\pm 450 \times 570 \mu \mathrm{m}$. Rhizoids hyaline, $15-20 \mu \mathrm{m}$ wide,

* National Botanical Institute, Private Bag X101, 0001 Pretoria MS received: 1999-01-18 some with internal mycorrhizal strands. Leaves overlapping, suberect, or incurved to widely spreading, upper margin undulating, often notched or lobed, lobes angular or rounded, sometimes very variable in shape, shorter or longer than wide, slightly decurrent, succubously inserted; in male plants leaves (Figure 1A-E) 875-1500 $(-2050) \times 875-1875 \mu \mathrm{m}$, generally narrower below; in female plants mostly larger (Figure 1F-J), 1625-2000 $\times$ $1300-1625 \mu \mathrm{m}$, also narrower below, at pseudoperianth often larger, up to $2250 \times 3025 \mu \mathrm{m}$, but narrower below; margins with 3 or 4 well-spaced papillae, generally sessile but near leaf base raised on 1 or 2 basal cells. Leaf cells thin-walled, not appreciably different in male and female plants, at upper margins (Figure $1 \mathrm{~L}$ ) rectangular across, occasionally isodiametric, $32.5-42.5 \times 40.0-67.5$ $\mu \mathrm{m}$, at lateral margins long-rectangular, 80-100 $\times$ 37.5-42.5 $\mu \mathrm{m}$; upper laminal cells 5- or 6-sided, 62.5-75.0 $\times$ 50.0-62.5 $\mu \mathrm{m}$; middle laminal cells $112.5-162.5 \times 50.0-67.5 \mu \mathrm{m}$; basal cells $125.0-162.5 \times$ $55-80 \mu \mathrm{m}$. Oil bodies absent in the material examined; chloroplasts $\pm 5 \mu \mathrm{m}$ diam. (Figure $1 \mathrm{M}$ ).

Dioicous. Antheridia dorsal on stem, near apex very young, spaced, toward base mature, in groups (Figure $2 \mathrm{~A}-\mathrm{C}$ ), short-stalked, globose, $\pm 250 \mu \mathrm{m}$ diam., subtended by perigonial bracts (Figure $1 \mathrm{R}-\mathrm{V}$ ), at maturity fairly large, $450-550 \times 150-220 \mu \mathrm{m}$, when 2 adjacent ones joined together, $320-430 \mu \mathrm{m}$ wide, marginal cells $67.5-95.0 \times 35-40$, cells in interior 4-6-sided, 100-125 $\times 25.0-32.5 \mu \mathrm{m}$, above with finger-like appendages, $150-250 \mu \mathrm{m}$ long, tapering to apices. Archegonia in a row dorsally along stem (Figure 2D), naked, sometimes 2 adjacent ones becoming fertilised. Pseudoperianth (Figure IW, X) cupulate, about as tall as leaves (Figure $2 \mathrm{E}, \mathrm{F})$, up to $2125 \mu \mathrm{m}$ long, flaring widely from narrow base, $\pm 750 \mu \mathrm{m}$ wide, across mouth $\pm 3325 \mu \mathrm{m}$ wide undulating, with folds or pleats and \pm 11 irregular projections, $400-450 \mu \mathrm{m}$ long and $\pm 550 \mu \mathrm{m}$ wide across base, at margin with 19 or 20 sessile papillae, sometimes laterally incised, rarely 2 adjacent pseudoperianths partly joined; cells comparable in shape and size to those of leaves. Capsules globose, $\pm 850 \mu \mathrm{m}$ diam., walls bistratose, cells of inner layer irregularly shaped (Figure $1 \mathrm{Y})$, roughly rectangular, trapezoidal or triangular, $22.5-57.5 \times 27.5-45.0 \mu \mathrm{m}$, each cell wall with (1)2 or 3 

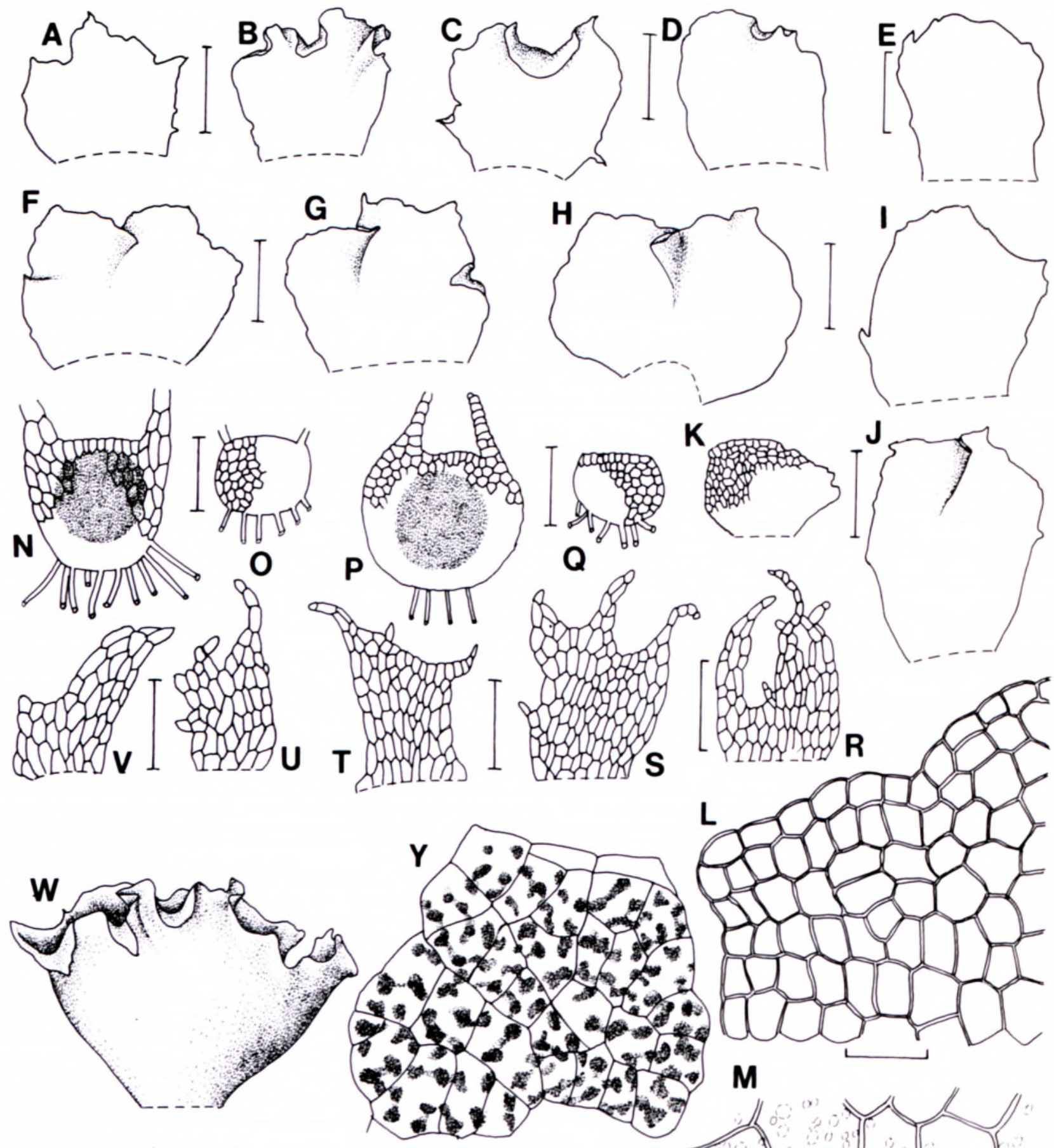

$\mathbf{L}$
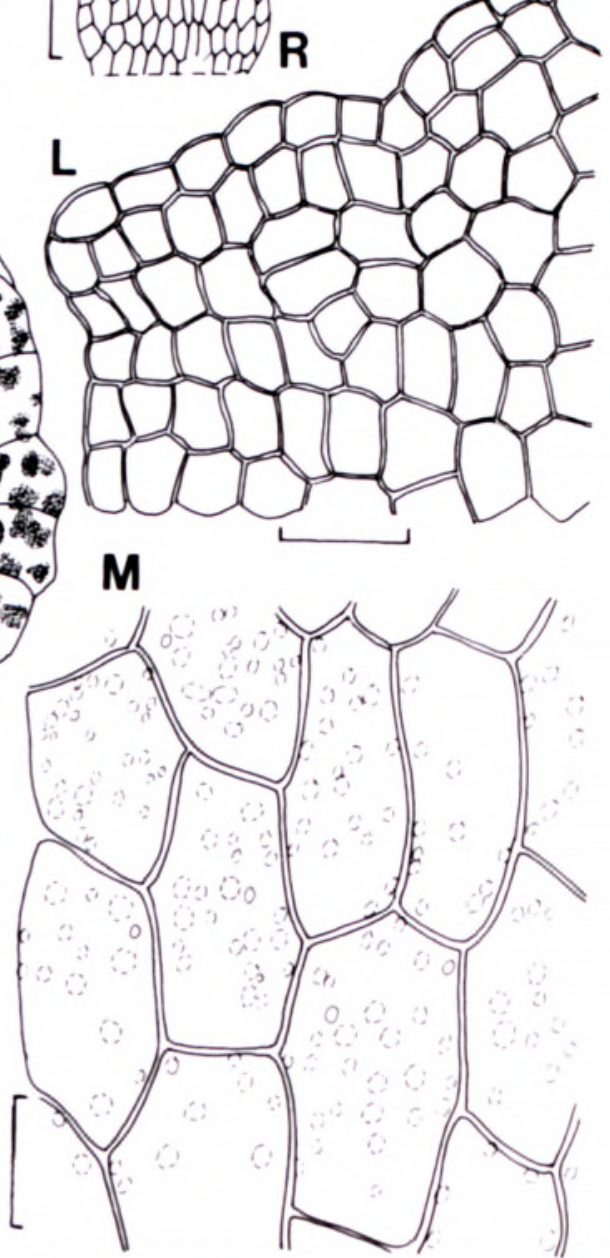

FIGURE 1.-Fossombronia hyalorhiza. A-E, male leaves; F-J, female leaves; K, apical leaf of old female stem; L, detail of leaf margin; M, median leaf cells with chloroplasts (oil bodies disintegrated); $\mathrm{N}, \mathrm{c} / \mathrm{s}$ male stem apex; $\mathrm{O}, \mathrm{c} / \mathrm{s}$ male stem base; $\mathrm{P}, \mathrm{c} / \mathrm{s}$ female stem apex; $\mathrm{Q}, \mathrm{c} / \mathrm{s}$ female stem base; R-V, perigonial bracts; W, pseudoperianth from side; X, opened pseudoperianth; Y, cells in inner capsule wall; Z, c/s seta. A-J, N, O, R-V, Y, Z, S.M. Perold 3867; K-M, W, X, S.M. Perold 3431; P, Q, S.M. Perold 3393. Scale bars: A-K, W, X, 500 $\mu$ m; L. Z, $100 \mu \mathrm{m} ; \mathrm{M}, \mathrm{Y}, 50 \mu \mathrm{m} ; \mathrm{N}-\mathrm{V}, 250 \mu \mathrm{m}$. Artist: G. Condy. 

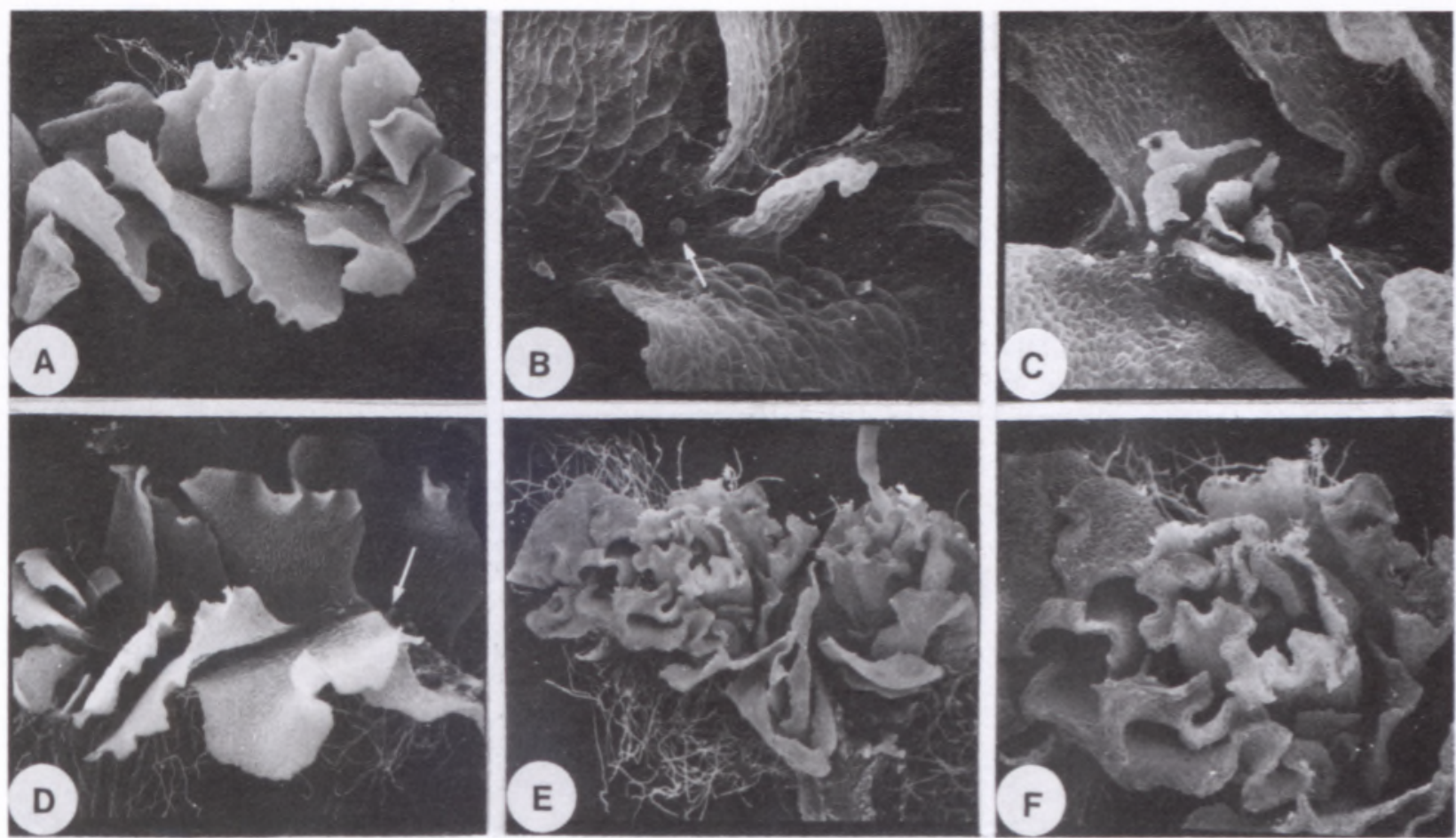

FIGURE 2-Fossombronia hyalorhiza. A, male plant with small perigonial bracts near apex of shoot; B, close-up view of perigonial bracts and very young antheridium (indicated by arrow); C, perigonial bracts and antheridia (indicated by arrows) near base of shoot; D, female plant with archegonia (one indicated by arrow); E, furcate female shoot, each branch with a pseudoperianth; F, close-up of pseudoperianth and surrounding leaves from above. A-D, S.M. Perold 3409; E, F, S.M. Perold 3902. A, × 8.3; B, × 38.8; C, × 29 ; D, E, × 10 ; F, × 20.

dark brown, nodular and sometimes semi-annular thickenings. Seta $1.5-4.0 \mathrm{~mm}$ long, in cross section (Figure 1Z) $230-250 \mu \mathrm{m}$ diam., 7 or 8 cells across. Spores brown to deep brown, hemispherical, $40.0-57.5 \mu \mathrm{m}$ diam. in some populations, in others $55.0-67.5 \mu \mathrm{m}$, including ridges (or spines) projecting at margins; distal face (Figure 3A-D) convex, with 6-8(9) irregular, straight or curved, short or long ridges across, 5.0-7.5 $\mu \mathrm{m}$ high, sometimes furcate, branches then running in different directions but often \pm parallel down sides of spore, \pm 7.5 $\mu \mathrm{m}$ apart, crests crenulate, between bases faint crossstriations and occasionally low, scattered papillae, rarely with complete or incomplete areolae $\pm 10 \times 7.5 \mu \mathrm{m}$, sometimes with a central inclusion; proximal face
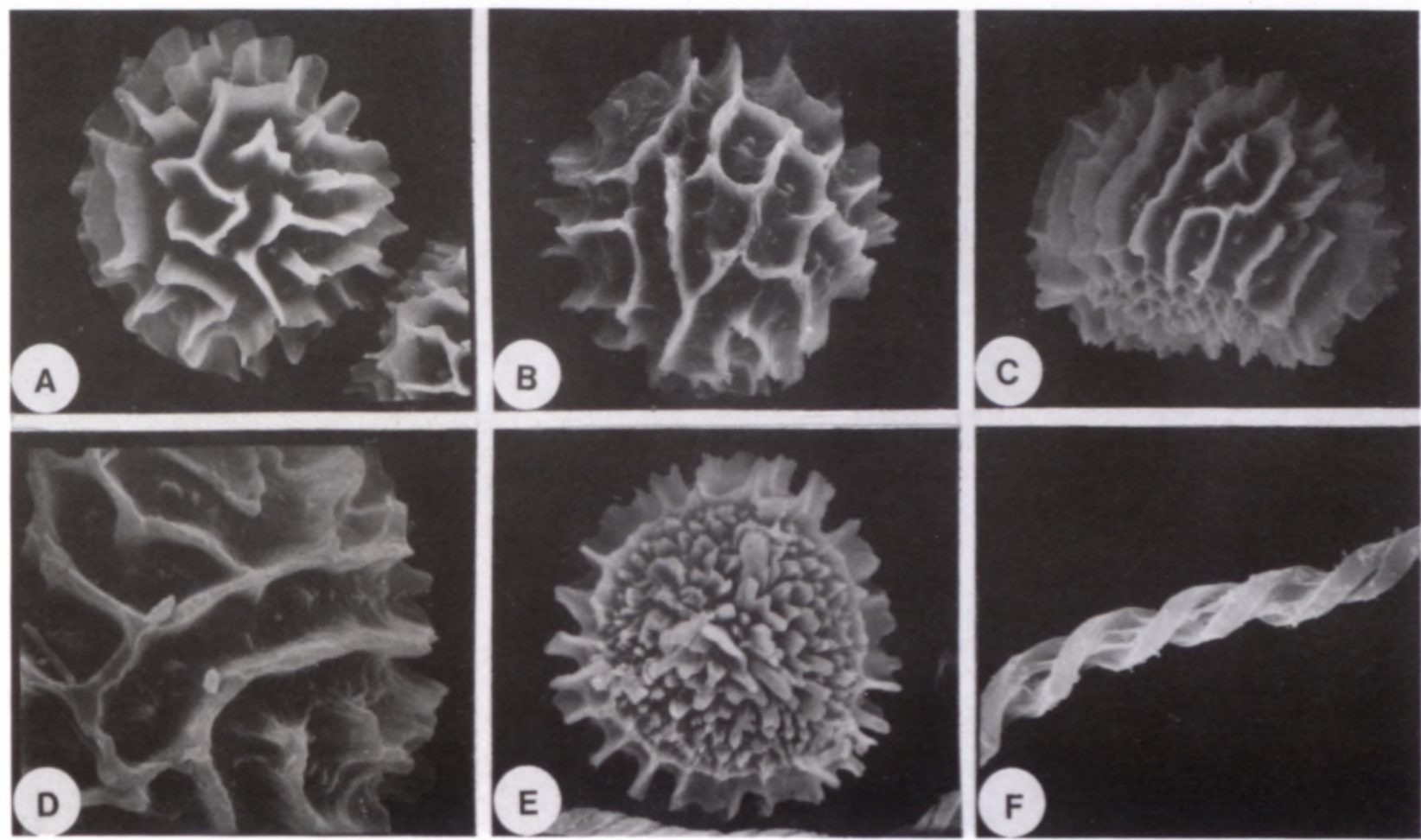

FIGURE 3.-Fossombronia hyalorhiza. A-E, spores; F, elater. A, B, distal face; C, side view of distal face; D, detail of part of distal face; E, proximal face. A, S.M. Perold 3903; B, D, F, S.M. Perold 3431; C, S.M. Perold 3902; E, S.M. Perold 3904. A, × 658; B, × 734; C, E, × 734; $\mathrm{D}, \times 1193 ; \mathrm{F}, \times 1285$. 
(Figure 3E) mostly flat, triradiate mark absent, but occasionally elements of ornamentation lined up to form part of 1 or 2 radii, inner area densely covered with coarse, irregular, erect, platelike projections or even amorphous 'blobs', in between and around circumference dotted with spinules and papillae, at spore periphery up to 25 'spines' ('ends' of ridges) projecting 5.0-7.5 $\mu \mathrm{m}$ and incompletely joined by a membranous wing or perispore, its margin crenulate or entire. Elaters (Figure 3F) light brown, $100.0-227.5 \times 7.5-10.0 \mu \mathrm{m}$, tapering to tips and sometimes ending in a loop, $5 \mu \mathrm{m}$ wide, 3 -spiral entirely or only in middle, ends 2 -spiral, very rarely partly 4 - or 5 -spiral, often faintly papillose.

Fossombronia hyalorhiza was collected several times (November 1995, October 1997) at four different localities in the Northern and Western Cape (Figure 4), which is in the winter rainfall area of southern Africa. This is referred to as the Fynbos Biome (sclerophyllous, microphyllous vascular plant vegetation) (Cowling et al. 1997; Rutherford 1997), or else the area is called the Cape Region (phytogeographic region based on the distribution of vascular plants) (Cowling \& Hilton-Taylor 1997). The four localities referred to above, (listed from north to south), are as follows: Matsikama Mountains, on plateau, east of Vanrhynsdorp; the type locality at Sandrivier, northeast of Op-die-Berg; Uitkyk Pass in the Cederberg Reserve; at the top of Gydo Pass, north of Prince Alfred Hamlet. According to Low \& Rebelo (1996) the vegetation type in these localities is Mountain Fynbos. The plants grow at seepage areas, near storm water furrows or at streams, on light brown or greyish, gravelly soil, containing quartz crystals. Mosses found with the type specimen are Pleuridium ecklonii (C.Müll.) Snider and Campylopus sp. A Drosera sp. was also growing with this collection, indicating that the soil is nitrogen-poor. The specific epithet hyalorhiza, meaning 'having colourless rhizoids', was chosen to distinguish this species from a sterile, undescribed Fossombronia species with purple rhizoids, which was mixed with some of the specimens with colourless rhizoids. Epithets like leucorhiza and porphyrorhiza have previously been used for Fossombronia species. In order to minimise damage to the specimens, it is, however, not possible to examine the rhizoids of every plant in the collections.

F. hyalorhiza can be distinguished by its colourless rhizoids; stems with a purple, \pm central core, persisting in older shoots, but 'tailing' off in young ones; undulating, suberect to spreading leaves and spores with the distal face bearing 6-8(9), ridges, which are sometimes parallel, at other times furcate, the branches often running in different directions. The spore ornamentation is fairly constant in all the specimens that were studied by light microscope as well as by scanning electron microscope.

From the northern, summer rainfall area of southern Africa, another new species with colourless rhizoids, $F$. straussiana (Perold 1997a), has been described. It differs from $F$. hyalorhiza by being monoicous, its leaves are densely imbricate and highly convoluted, with basal appendages partly curved around the antheridia and its spores are ornamented with incomplete areolae containing fine inclusions.

To compare the two southern African species that have colourless rhizoids with $F$. husnotii Corb., a loan of

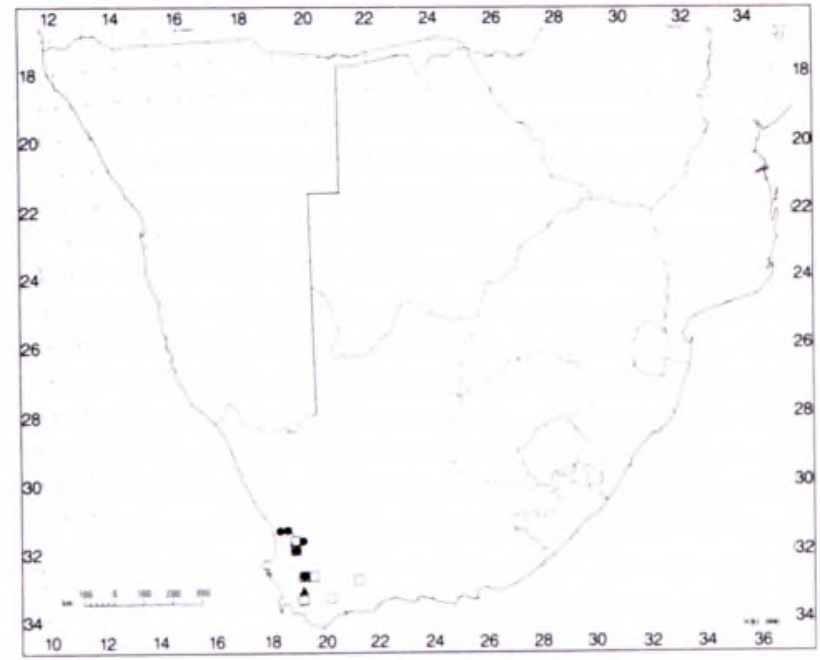

FIGURE 4-The distribution of Fossombronia hyalorhiza, $-F$ marindae, $\boldsymbol{\Delta}$; and $F$. monticola, $\boldsymbol{\square}$, in Western Cape.

the type material was requested from the Société Nationale des Sciences Naturelles et Mathématiques de Cherbourg, but it was not available. Samples of specimens of $F$. husnotii (with colourless rhizoids) collected in Madeira by Dr T. Arts were kindly sent by him. Examination of the spores of these samples by SEM, demonstrated once again that the ornamentation on the distal face of $F$. husnotii spores is extremely variable, 'ranging from discrete spines to \pm parallel lamellae or irregular areolae' (Paton 1973). In F. hyalorhiza spores there are no discrete spines on the distal face, only the 'ends' of the ridges which project around the periphery of the spore, with some papillae between them. The ornamentation on the proximal face is also much coarser and denser. Jones \& Harrington (1983) report 'the constant production of descending stolons and tubers (that) form useful diagnostic characters' in $F$. husnotii. These are absent in $F$. hyalorhiza, and new growth is often initiated from old stem apices.

The two southern African species with colourless rhizoids, $F$. straussiana and $F$. hyalorhiza, are thus shown to be distinct from $F$. husnotii.

\section{Fossombronia marindae Perold, sp. nov.}

Plantae repentes, arcte conturbatae. Folia imbricata, suberecta, forma irregulari, interdum lobata. Solum plantae femineae visae. Pseudoperianthium campanulatum; ore undulato, saepe leviter vel profunde lobato. Sporae $42.5-55.0 \mu \mathrm{m}$ diametro, superficie distali exquisite ornata, cum 7 vel 8 cristis trans diametrum, inter cristos cum spinulis multis tenuibus. Elateres $112.5-230.0 \times 7.5 \mu \mathrm{m}$, multi bis spirales, alii longitudinem secus alterne bis et ter spirales.

TYPE.-Western Cape, 3319 (Worcester): Worcester, at northern outskirts of town, Rustig Chalets, against moderate slope, behind camp sites nos. 1 and 2, on damp, clayey soil, in partial shade, (-CB), M. Koekemoer 1415 (PRE, holo.).

Since female plants were the only ones seen, the following description pertains to them only. Plants mediumsized, creeping', in closely crowded stands, clear green. 
turning brown and translucent with age; shoots simple (Figure 6A), up to $8 \mathrm{~mm}$ long, $\pm 1.75 \mathrm{~mm}$ high, often gradually becoming lower toward base, $\pm 1.5 \mathrm{~mm}$ wide, occasionally once furcate, apical segments mostly short, $0.8-1.5 \mathrm{~mm}$ long, moderately divergent, rarely with lateral shoots apparently arising from buds. Stems prostrate, green, occasionally arched (Figure 6D), some growing from apices of old shoots, apically (Figure 5Q) fleshy, in cross section $\pm 350 \mu \mathrm{m}$ ( 10 cell rows) high, up to $600 \mu \mathrm{m}$ wide, tapering proximally and basally (Figure $5 R$ ) \pm 350 $\times 300 \mu \mathrm{m}$, plano-convex. Rhizoids purple, $10-15 \mu \mathrm{m}$ wide. Leaves overlapping, suberect, undulating, succubously inserted on stem, often decurrent, those lateral to pseudoperianth near stem apex larger, widely obovate, 1575-2625 × 1575-2375 $\mu \mathrm{m}$, below 1000-1125 $\mu \mathrm{m}$ wide (Figure $5 \mathrm{~N}$ ), shape of other leaves (Figure 5A-L) irregular, sometimes lobed, shorter than wide above, $1150-1500 \times 1225-2250 \mu \mathrm{m}$, narrower below, 800-1250 $\mu \mathrm{m}$, rarely 2 leaves joined (Figure $5 \mathrm{M}$ ) for some distance above their bases and produced at branching off of lateral shoot between it and main axis; margins with 2-4 widely spaced, sessile papillae. Leaf cells thin-walled, at upper margins (Figure 5O) subquadrate to rectangular across, $25-40 \times 37.5-52.5 \mu \mathrm{m}$, at lateral margins longrectangular, $40.0-92.5 \times 25-30 \mu \mathrm{m}$; upper laminal cells 5- or 6-sided, $40.0-52.5 \times 30-40 \mu \mathrm{m}$; middle laminal cells $72.5-90.0 \times 42.5-65.0 \mu \mathrm{m}$; basal cells $100.0-112.5$ $\times 50.0-87.5 \mu \mathrm{m}$. Oil bodies (Figure $5 \mathrm{P}$ ) smooth, globose and shiny, $2-15$ per cell, $5.0-7.5 \mu \mathrm{m}$ diam.; chloroplasts mostly spherical, 2.5-5.0 diam.

Dioicous presumably, but no plants with antheridia seen. Archegonia in a row dorsally along stem (Figure 6A), naked, often obscured by suberect leaves. Pseudoperianth campanulate (Figure 5T), generally very close to stem apices (Figure 6C), which are often raised, sometimes 2 alongside each other or else 2 in acropetal sequence (Figure 6E), 2250-2475 $\mu \mathrm{m}$ long, projecting \pm $750 \mu \mathrm{m}$ above leaves, widely flaring above, from narrow, slightly stipitate base, up to $6090 \mu \mathrm{m}$ wide across mouth, margin undulating, often shallowly to deeply lobed (Figure 5S), with \pm 6 widely spaced papillae, mostly at angulations, sessile, rarely raised on basal cells, sometimes along one side deeply incised (Figure 6F); cells comparable in shape and size to those of leaves. Capsules globose, up to $1375 \mu \mathrm{m}$ diam., wall bistratose, cells of inner layer polygonal, (35-)55-70 $\times$ (20.0-) 30.0-62.5 $\mu \mathrm{m}$, each cell wall (Figure 5V) with $1-3$, rarely 4 , dark brown, nodular and occasionally semi-annular thickenings. Seta $1.8-8.0 \mathrm{~mm}$ long, $300-350 \mu \mathrm{m}$ or 10 cell rows diam. (Figure $5 \mathrm{U}$ ). Spores light brown, hemispherical, 42.5-55.0 $\mu \mathrm{m}$ diam., including ridges projecting at periphery; distal face (Figure 7A-D) convex, elaborately ornamented with 7 or 8 ridges across face, partly parallel, otherwise branched, rather thin, curved or winding somewhat, slightly undulating to lightly pleated, up to $7.5 \mu \mathrm{m}$ high and $5-10 \mu \mathrm{m}$ apart, some ridges anastomosing and forming closed areas, others open-ended, crests crenulate or eroded, space between ridges containing numerous slender spinules in 1 or more rows, crowned with fine granules, and some basally connected to sides of ridges or to one another by faint buttressing lines; proximal face (Figure $7 \mathrm{E})$ without triradiate mark, toward centre with irregular, prominent, as well as smaller protrusions and a few short ridges, surrounded by numerous fine spinules in 4 or 5 irregular rows, some coalesced into small ridges, around spore periphery a variable number of projecting spines, mostly joined by a $5.0-7.5 \mu \mathrm{m}$ wide, incomplete membranous wing with crenulate margin. Elaters (Figure 7F) pale straw-coloured, $112.5-230.0 \times \pm 7.5 \mu \mathrm{m}$, tapering to tips, $5 \mu \mathrm{m}$ wide, finely papillose, many entirely 2 -spiral, others alternately 3-spiral, 2-spiral, 3-spiral and 2-spiral along length or else 2-spiral, 3-spiral and 2-spiral, some 2 -spiral in one half and 3-spiral in the other.

Fossombronia marindae was collected in August 1998 on the outskirts of Worcester in the Western Cape (Figure 4) by Ms Marinda Koekemoer, after whom I have named it, in grateful recognition of much help and support, especially with fieldwork. It is so far only known from the type locality, where it was growing together with $F$. densilamellata S.W.Arnell and $F$. spinosa (Perold 1999: 32) on light brown, clayey soil, containing some small quartz crystals. This locality falls in the winter rainfall Fynbos Biome (Cowling et al. 1997; Rutherford 1997), and more specifically, in the Little Succulent Karoo vegetation type (Low \& Rebelo 1996) which is adapted to rather dry conditions. The plants were sporulating profusely and the species must be more widespread than the single locality in Worcester suggests.

Schuster (1992) remarked that, 'one interesting feature, which apparently has not been noted for the genus', is as follows, "leaves produced on either side (inner sides) at the base of a dichotomy are coalesced with each other for some distance above their bases'. He compared this with "similar paired (or bilobed) leaflike structures (that) also occur in Phyllothallia, at the fork of a dichotomy'. In $F$. marindae this feature was noticed at the branching off of a lateral shoot from the main axis, but it has also occasionally been observed at an apical dichotomy in another, undescribed southern African species of Fossombronia. It is not thought to be of any taxonomic significance in discriminating between species.

F. marindae can be recognised by usually split-open pseudoperianths with undulating margins at the mouth; they are often situated very close to the stem apices and sometimes on short shoots which are apically slightly raised. The most important character, however, is the very elaborate spore ornamentation with 7 or 8 ridges across the distal face and numerous spinules between. It is surely one of the most beautiful in the entire genus and not to be confused with that of any other species.

\section{Fossombronia monticola Perold, sp. nov.}

Plantae repentes, sublaxae. Folia imbricata, suberecta vel patentia, undulata, saepe 2-vel 3-lobata, margine cum processibus nonnullis brevibus spinosis. Dioicae. Antheridia in plantis masculis bracteis obtecta. Pseudoperianthium campanulatum; ore undulato, in 11 vel 12 lobis diviso, marginibus cum usque ad 35 prominentiis spinosis. Sporae 35-50 $\mu \mathrm{m}$ diametro; superficie distali cum 9-11 cristis, interdum subparallelis, ceteris cursibus variis. Elateres 92.5-147.5 longi, plerumque bis spirales, rarissime ter spirales. 

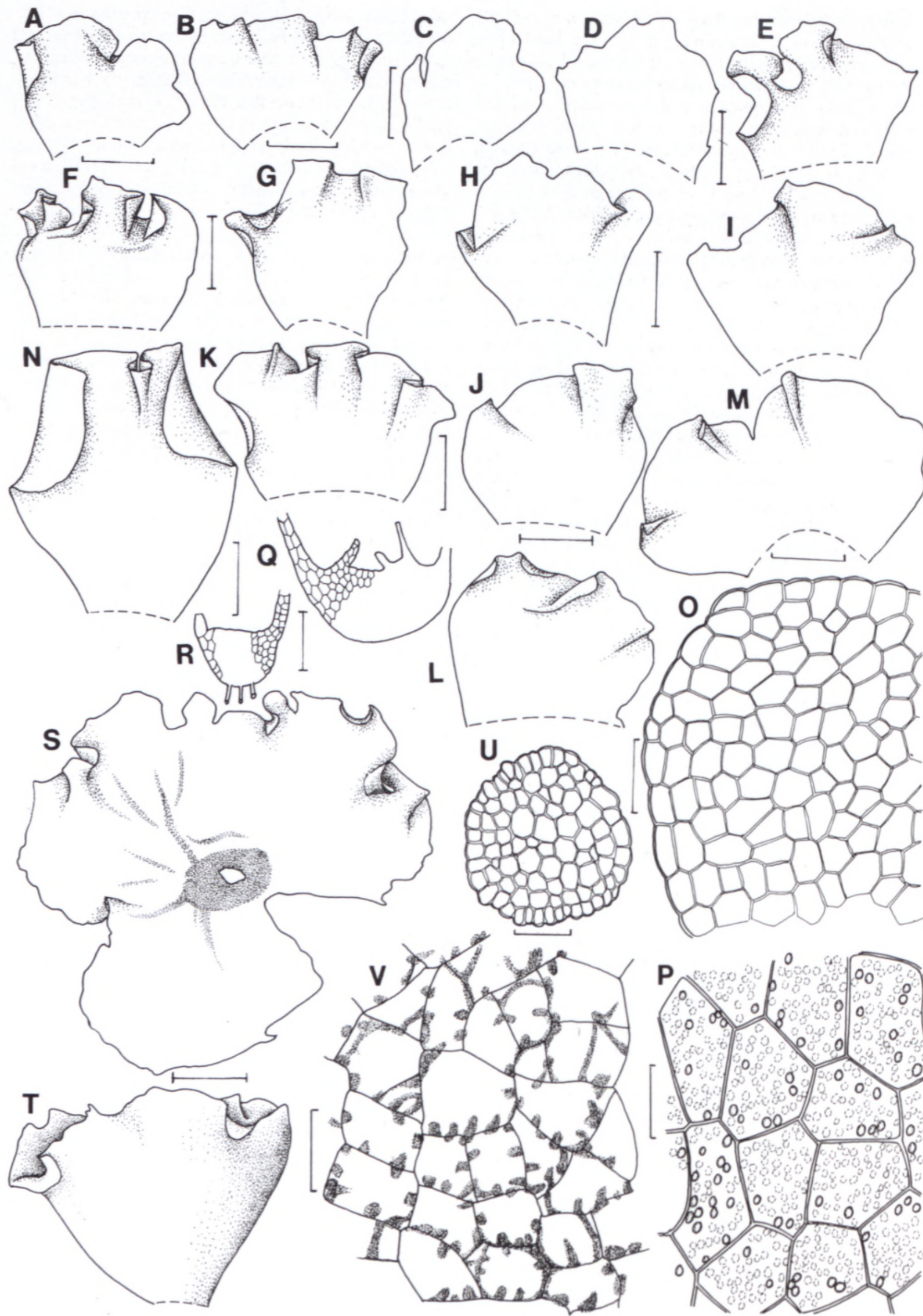

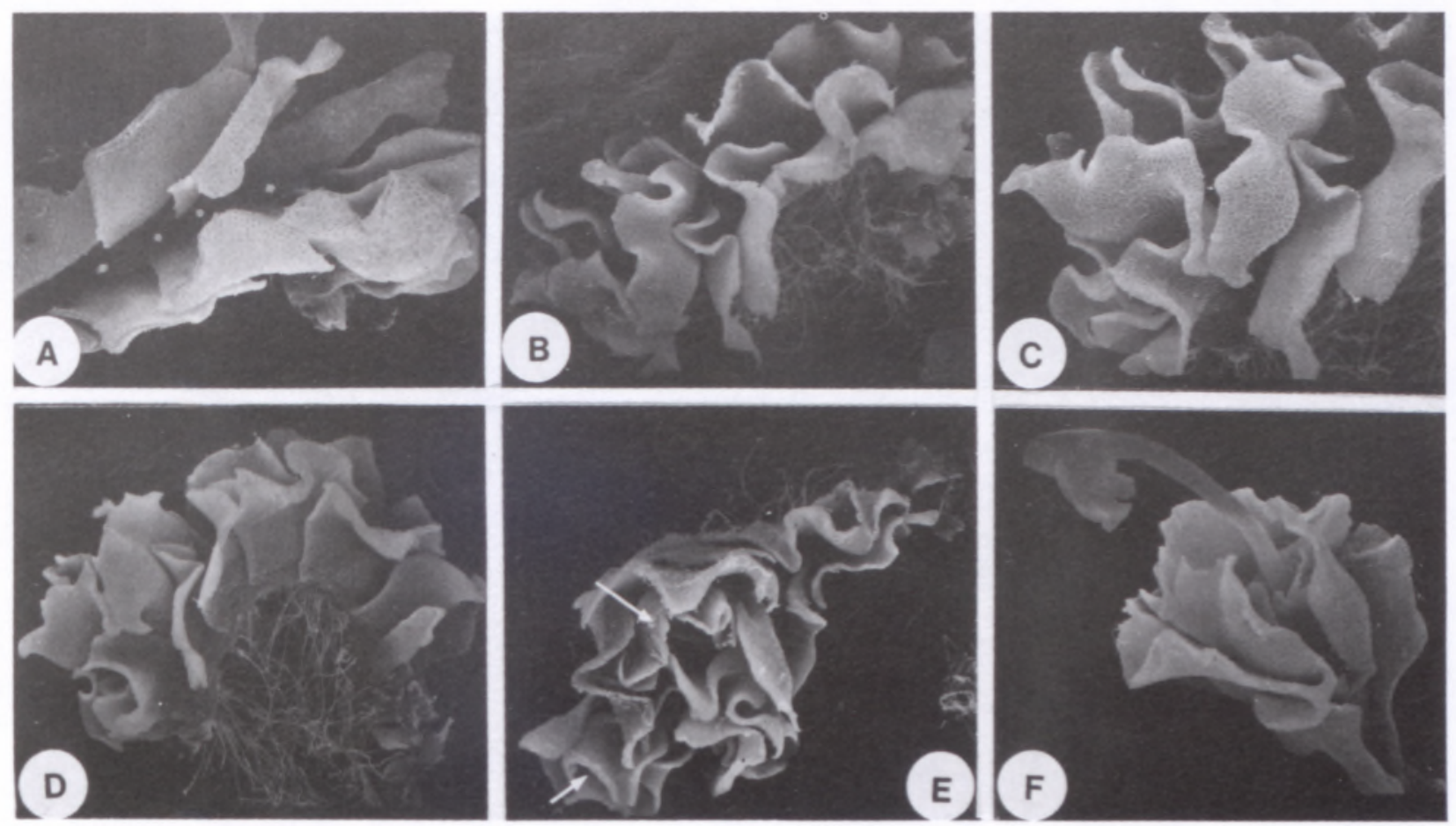

FIGURE 6.-Fossombronia marindae. A, female shoot with row of archegonia; B, young pseudoperianth near apex of branch; C, close-up view of young pseudoperianth; D, shoot seen from side, showing arched stem with leaves; E, two pseudoperianths in acropetal sequence, distal one hidden (indicated by arrows); F, pseudoperianth slit at side, showing seta emerging from torn calyptra, capsule dehisced. A-F, $M$. Koekemoer 1415. A, C, × 18.4; B, F, × 13.8; D, × 11; E, × 13.4.

TYPE.-Western Cape, 3219 (Wuppertal): Cederberg, between Elizabethfontein turnoff and Pakhuis Pass, at seepage area, on moderate mountain slope on northern side of Pakhuis Pass, under Stoebe plumosa and Restio bushes, (-AA), M. Koekemoer 1397 (PRE, holo.).

Plants smallish to medium-sized, creeping, in rather loose stands, light green, becoming translucent with age; shoots simple or once/twice shortly furcate, occasionally with 1 or 2 lateral branches, frequently arising basally (or sometimes laterally) from tuberous apices of old stems, the latter $\pm 350 \times 500 \mu \mathrm{m}$ (Figure 8R), flanked by smaller reddish leaves, rounded, $\pm 750 \times 875 \mu \mathrm{m}$ (Figure $8 \mathrm{O}$ ), proximally naked and tapering, $\pm 5 \mathrm{~mm}$ long; male plants up to $5.5 \times 2.4-2.5 \mathrm{~mm}, \pm 1.0 \mathrm{~mm}$ high; female plants larger, up to $9 \times \pm 2.8 \mathrm{~mm}, \pm 1.6 \mathrm{~mm}$ high. Stems pros-
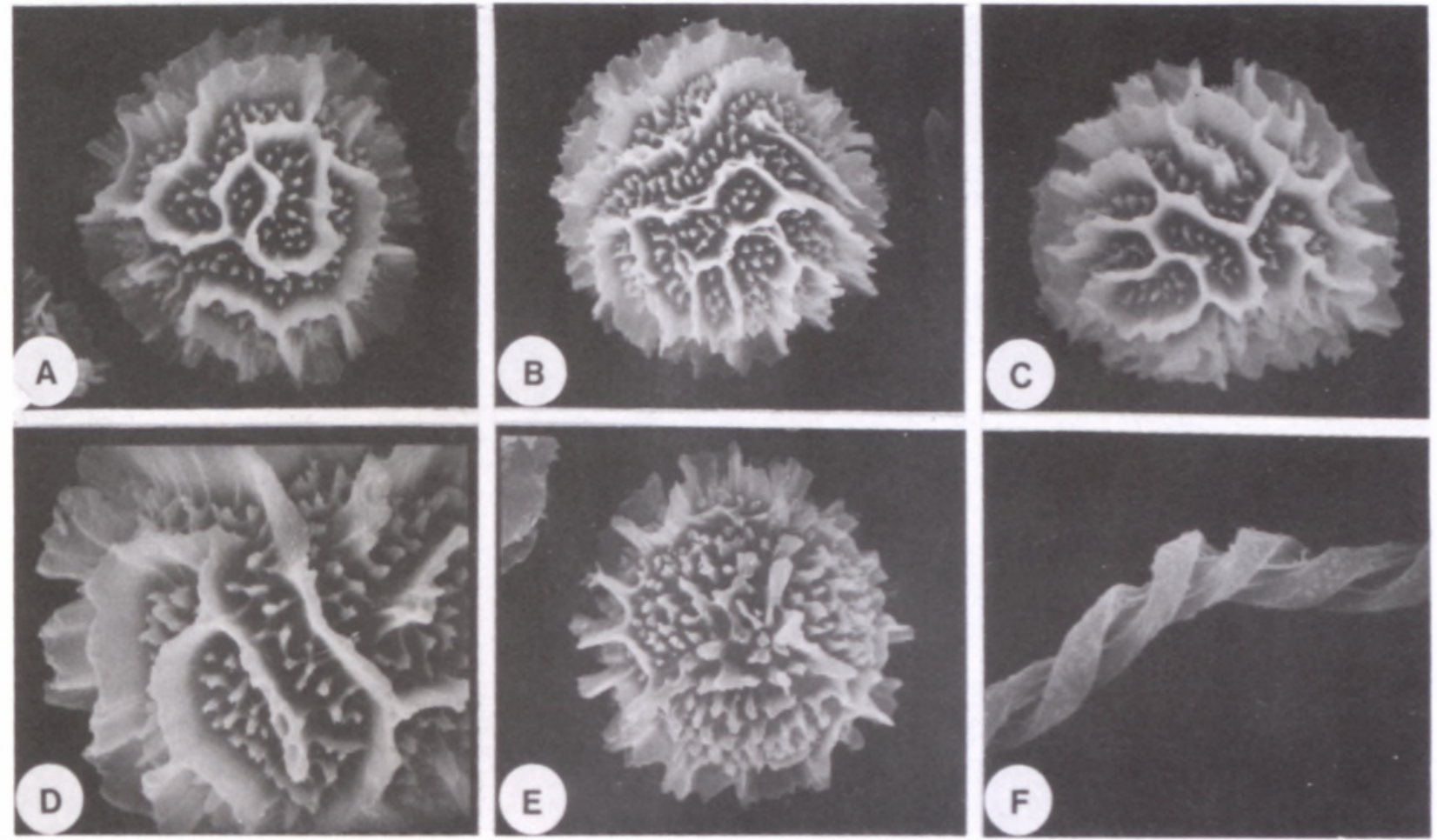

FIGURE 7.-Fossombronia marindae. A-E, spores; F, elater. A, B, distal face; C, side view of distal face; D, detail of part of distal face; E, proximal face. A-F, M. Koekemoer 1415. A, × 879; B, × 910; C, × 876; D, × 1338; E, × 780; F, × 1506 

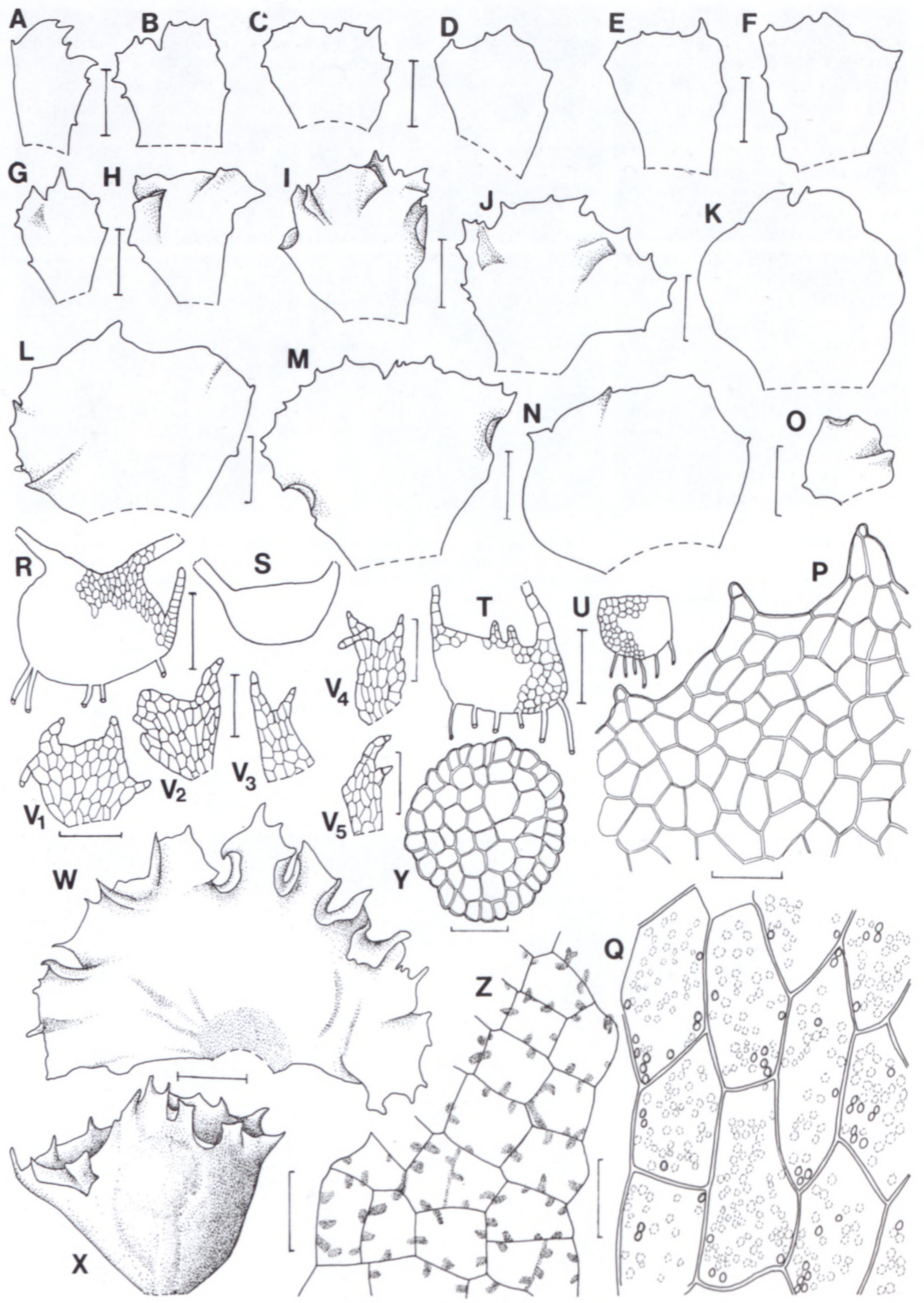

FIGURE 8 - Fossombronia monticola. A-F, male leaves; G-N, female leaves; $\mathrm{O}$, small leaf from old, tuberous stem; $\mathrm{P}$, detail of leaf margin; $\mathrm{Q}$. median leaf cells with oil bodies (solid lines) and chloroplasts (dotted lines); R, c/s old tuberous stem; S, c/s male stem apex; T, c/s female stem apex; U, c/s female stem base; $V_{1}-V_{5}$, perigonial bracts; W, opened pseudoperianth; X, pseudoperianth from side, showing outline of capsule within; Y, c/s seta; Z, cells in inner capsule wall. A-Z, M. Koekemoer 1397. Scale bars: A-O, W, X, $500 \mu \mathrm{m} ; \mathrm{P}, \mathrm{Y}, 100 \mu \mathrm{m} ; \mathrm{Q}, \mathrm{Z}$, $50 \mu \mathrm{m} ; \mathrm{R}-\mathrm{U}, \mathrm{V}_{1}-\mathrm{V}_{\mathrm{s}}, 250 \mu \mathrm{m}$. Artist: G. Condy. 
trate, occasionally arched or bent, green, in cross section plano-convex, in male plants at apex (Figure 8S) $180-200 \mu \mathrm{m}$ ( \pm 8 cell rows) high, $340-370 \mu \mathrm{m}$ wide, at base $\pm 200 \times 380 \mu \mathrm{m}$; in female plants at apex $\pm 210 \times$ $400 \mu \mathrm{m}$ (Figure $8 \mathrm{~T}$ ), tapering to base, $\pm 200 \times 250 \mu \mathrm{m}$ (Figure 8U). Rhizoids deep reddish pink, 12.5-20.0 $\mu \mathrm{m}$ wide. Leaves overlapping, suberect to spreading, upper margin undulating, often 2- or 3-lobed and with several short spinous projections, variable in size but mostly larger proximally than distally, somewhat fan-shaped, generally wider above and gradually narrowing below, sometimes decurrent, succubously inserted; in male plants (Figure 8A-F) (725-) 1000-1350 × 725-1350 $\mu \mathrm{m}$, below $550-750 \mu \mathrm{m}$ wide; in female plants (Figure $8 \mathrm{G}-\mathrm{N})$ mostly larger, $1500-2000 \times 1700-2125 \mu \mathrm{m}$, below $625-1125 \mu \mathrm{m}$ wide, margins with 11-16 papillae, rounded or conical, $15.0-32.5 \times 17.5-22.5 \mu \mathrm{m}$, sometimes collapsed, sessile or raised on a single basal cell (Figure 8P), otherwise on tiers of up to 3 cell rows, respectively consisting of 2,3 and 4 cells alongside each other and arranged in a triangle, $\pm 160 \mu \mathrm{m}$ long and 150 $\mu \mathrm{m}$ wide at base. Leaf cells thin-walled, generally somewhat larger in female plants, which are more common, hence their cell dimensions are given: at upper margins (Figure 8P), rectangular across or occasionally isodiametric, 32.5-37.5 × 45-65 $\mu \mathrm{m}$, at lateral margins longrectangular, 45-90 × 25.0-37.5 $\mu \mathrm{m}$; upper laminal cells 5- or 6-sided, 30-85 $\times 40-50 \mu \mathrm{m}$; middle laminal cells $100-125 \times 55-65 \mu \mathrm{m}$; basal cells $132.5-150.0 \times 75-100$ $\mu \mathrm{m}$. Oil bodies (Figure $8 \mathrm{Q}$ ) generally faintly granular, not quite globose, shiny, $8-17$ per cell, 3-5 $\mu \mathrm{m}$ diam.; chloroplasts mostly spherical, $\pm 5 \mu \mathrm{m}$ diam.

Dioicous. Antheridia dorsally along stem (Figure 9A-C), sometimes confined to proximal part only, in groups, short-stalked, globose, $\pm 170 \mu \mathrm{m}$ diam., subtended by perigonial bracts (Figure $8 \mathrm{~V}_{1}-\mathrm{V}_{5}$ ), size and shape rather variable, body $240-480 \times 120-350 \mu \mathrm{m}$, with up to 4 finger-like appendages, $70-140 \mu \mathrm{m}$ long and topped with a papilla, marginal cells $30.0-47.5 \times 50.0-77.5 \mu \mathrm{m}$, cells in interior 4-6-sided, $75-80 \times 30.0-42.5 \mu \mathrm{m}$. Archegonia in a row dorsally along stem, sometimes even distal to a pseudoperianth, occasionally 2 in acropetal sequence becoming fertilised. Pseudoperianth (Figures 8W, X; 9D-F) campanulate, about as tall as adjacent leaves, up to $1875 \mu \mathrm{m}$ long, flaring widely from narrow base, $\pm 750 \mu \mathrm{m}$ wide, across mouth $3300-3750$ $\mu \mathrm{m}$ wide, undulating, divided into 11 or 12 lobes, some up to $375 \times 625 \mu \mathrm{m}$, at margin \pm 35 spinous projections, 1-5 cells high and topped with a papilla; cells comparable in shape and size to those of leaves; sometimes laterally with loose outgrowths, $\pm 1250 \mu \mathrm{m}$ long and 3 cells wide. Capsules globose, $800-1250 \mu \mathrm{m}$ diam., walls bistratose, cells of inner layer (Figure $8 \mathrm{Z}$ ) irregularly shaped, roughly quadrangular, rectangular or trapezoidal, $32.5-45.0 \times 15-50 \mu \mathrm{m}$, each cell wall with $1-4$ dark brown, nodular thickenings, semi-annular thickenings rare. Seta up to $2 \mathrm{~mm}$ long, in cross section (Figure $8 \mathrm{Y}) \pm 330 \mu \mathrm{m}$ diam., 8 cells across. Spores light brown to deeper brown, hemispherical, 35-45(-50) $\mu \mathrm{m}$ diam., including ridges projecting at margins; distal face (Figure 10A-D) convex, covered with 9-11 branched and rejoined or discontinuous ridges, straight or curved, short or long, sometimes a few partly parallel to one another, others running in different directions, up to 5 $\mu \mathrm{m}$ apart and $\pm 3 \mu \mathrm{m}$ high, crests crenulate, between the bases of adjacent ridges, thin buttressing lines, occasionally joined across and forming areolae, their transverse walls fainter than the others, rarely a partly open ring formed around a central, star-shaped, spinous process (Figure 10C); proximal face (Figure 10E) mostly flat, triradiate mark absent, with fine granules surrounding inner coarse ones, sometimes joined up to form short, radiating ridges or larger 'blobs', around periphery \pm 26 spines, \pm
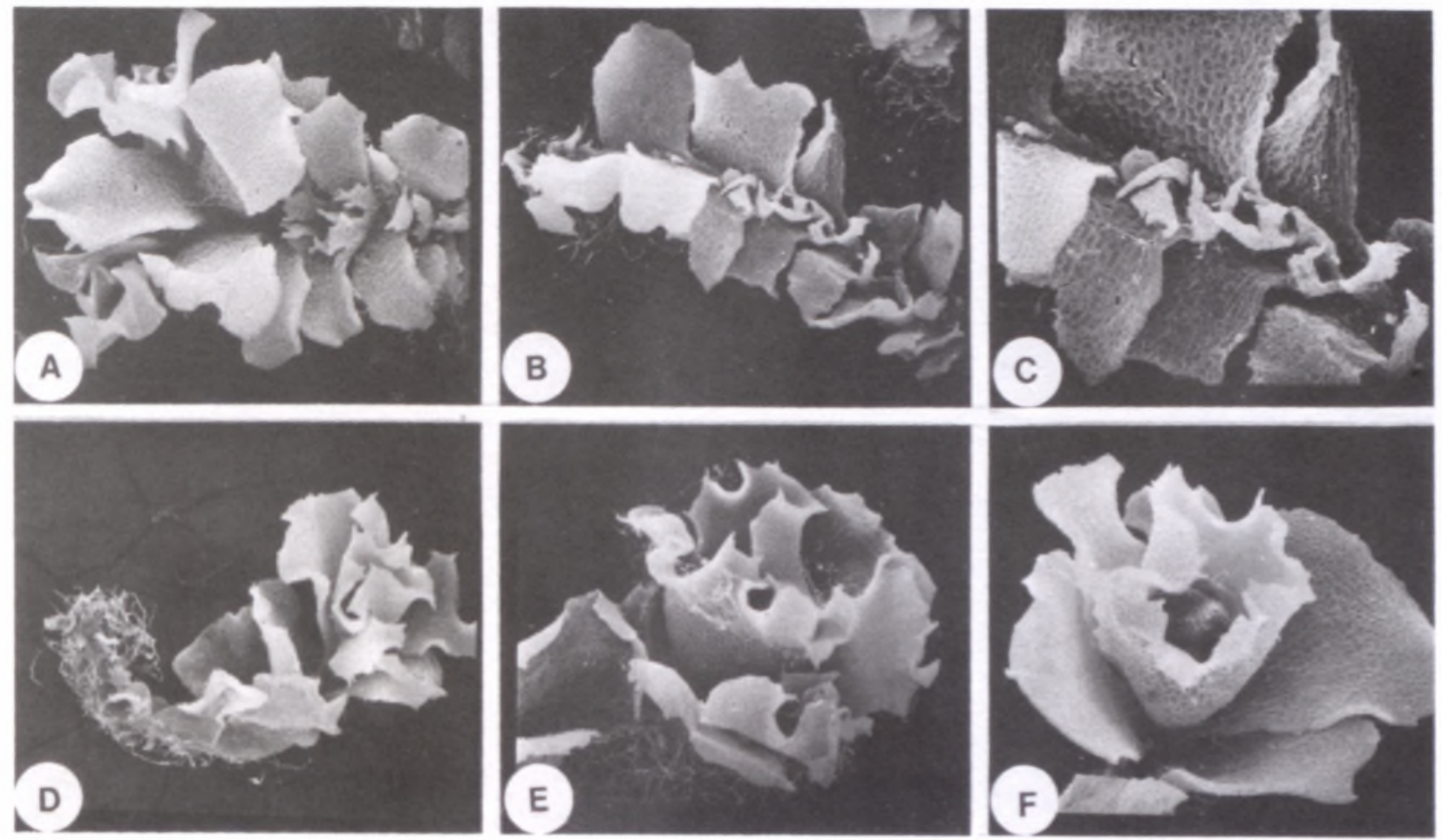

FIGURE 9.-Fossombronia monticola. A, furcate male shoot with perigonial bracts; B, simple male shoot with bracts and one antheridium; C, close-up of bracts and antheridium; D, female shoot with pseudoperianth; E, close-up of pseudoperianth; F, pseudoperianth with capsule from above. A-F, M. Koekemoer 1397. A, × 17; B, × 13.3; C, × 26; D, × 10; E, × 13.8; F, × 16.5 . 

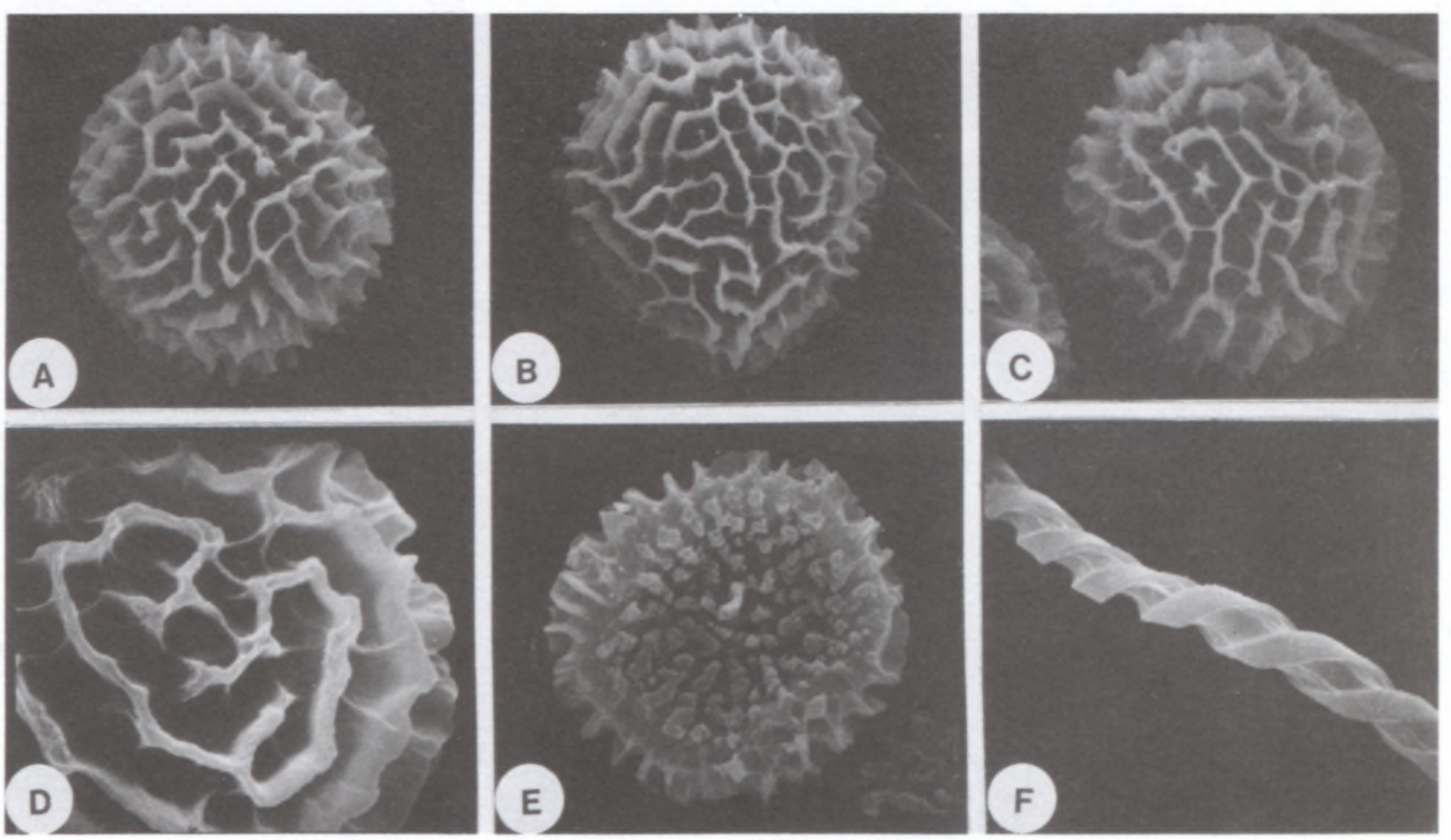

FIGURE 10.-Fossombronia monticola. A-E, spores; F, elater. A-C, distal face; D, detail of part of distal face; E, proximal face, A-F, M. Koekemoer 1397. A, × 759; B, × 794; C, × 940; D, × 1804; E, 840; F, × 1526.

$2.5 \mu \mathrm{m}$ high and mostly connected by a thin membranous wing or perispore. Elaters (Figure 10F) light brown, $92.5-147.5 \times 7.5 \mu \mathrm{m}$ and tapering to looped tips, mostly 2 -spiral, very rarely 3 -spiral, smooth.

Fossombronia monticola has fairly frequently been collected in the Western Cape (Figure 4). The localities, which also fall in the winter rainfall Mountain Fynbos vegetation type, are from north to south: Matsikama Mountains, on plateau east of Vanrhynsdorp; the type locality in the Cederberg; Uitkyk Pass, Cederberg; Gydo Pass, north of Prince Alfred Hamlet; Farm Merino, at foot of Waboomberg; Bain's Kloof; south of Tulbagh; Kogman's Kloof; Farm Zandrivier, near Seweweekspoort. The plants grow at seepage areas, often on soil pockets on vertical rock walls of mountain passes or on streambanks. Several of these localities are mountainous, hence the specific epithet, monticola. The type specimen was growing together with Riccia crozalsii Lev. and $R$. purpurascens Lehm., as well as a Fissidens sp. and a Jungermannia sp., on greyish to pale yellow soil, containing fine to rather large quartz crystals. Part of this collection had to be kept in cultivation for some weeks, to allow the spores to ripen. Repeated samplings of the spores were then taken to make sure that the specimen was not mixed with other Fossombronia species.

In one of my collections of $F$. monticola, Perold 3293 , from the Farm Zandrivier near Seweweekspoort, I noticed some leaves with few to many cells deeply stained with red and containing a dark, round, internally granular body, as I mentioned in F tumida (Perold $1997 \mathrm{c})$. Scattered cells containing spherical bodies, were also remarked on and illustrated by Sim (1926) and Arnell (1963) in their respective treatments of $F$. tumida. Perhaps it is possible that these cells had been parasitised by some organism.
Vegetatively $F$. monticola is quite a variable species, but it can generally be distinguished by somewhat fanshaped leaves that are 2- or 3-lobed and mostly wider above than below; the upper margin is undulating, and has several short spinous projections topped with a papilla; the pseudoperianth is campanulate, its mouth is divided into 11 or 12 lobes and the margin has up to 35 spinous projections; the distal face of the spores is covered with 9-11 irregular ridges, up to $5 \mu \mathrm{m}$ apart and sometimes joined by fainter transverse walls to form areolae.

The ornamentation on the distal face of the spores in $F$. monticola resembles that of $F$. montaguensis S.W.Arnell, but it differs from the latter by having lobed, undulate, not frilly leaves; each of the cells in the inner layer of the capsule wall in F. montaguensis (Perold 1997b), has several semi-annular thickenings, which are often ring-formed, whereas $F$. monticola capsule wall cells almost exclusively have nodular and only rarely any semi-annular thickenings; the new species is also more common.

The distal spore face ornamentation of $F$. monticola also bears some resemblance to that of $F$. rudis Scott \& Pike (1988) nom. inval. typ. non cit., from Stoke's Creek, Northern Territory, Australia, in that they depict and describe it as 'irregularly covered with thin scattered lamellae and spines'; vegetatively, however, the species differ greatly, F. rudis having interalia a pseudoperianth raised on a 'stalk into which the foot projects as a perigynium'.

\section{SPECIMENS EXAMINED}

Held at PRE. Bracketed numbers after collectors' name and number refer to the species in the text in alphabetical order, namely: F hyalorhiza (1), F marindae (2) and F. monticola (3). 
Koekemoer 1397 (type), 1408 p.p. (3), 1415 p.p. (type) (2).

S.M. Perold 3293, 3296, 3356 (3), 3393, 3409, 3431 (1), 3443, 3447 , $3448,3818,3844,3851,3864$ (3), 3867 (type) (1), 3871, 3883, 3884 . 3901 (3), 3902-3904 (1)

\section{ACKNOWLEDGEMENTS}

My deep thanks to Dr H. Stieperaere, Meise, for kindly refereeing this article and for his helpful suggestions. I also sincerely thank my colleagues at NBI, i.e. the curator of PRE, Ms M. Koekemoer, and also Mr J. Meyer, for their generous help with fieldwork. Dr Theo Arts, Belgium, is heartily thanked for his gift of Fossombronia specimens from Madeira (and elsewhere). Dr H.F. Glen is also thanked for translating the diagnoses into Latin. In addition, I extend my gratitude to Ms G. Condy for the drawings, Mrs A. Romanowski for developing and printing many photographs and to Ms D. Maree for typing the manuscript.

\section{REFERENCES}

ARNELL, S.W. 1963. Hepaticae of South Africa. Swedish Natural Science Council. Stockholm.

COWLING, R.M. \& HILTON-TAYLOR, C. 1997. Phytogeography, flora and endemism. In R.M. Cowling. D.M. Richardson \& S.M. Pierce, Vegetation of southern Africa. Cambridge University Press, Cambridge.

COWLING, R.M., RICHARDSON, D.M. \& MUSTART, P.J. 1997. Fynbos. In R.M. Cowling, D.M. Richardson \& S.M. Pierce,
Vegetation of southern Africa. Cambridge University Press, Cambridge.

JONES, E.W. \& HARRINGTON, A.J. 1983. The hepatics of Sierra Leone and Ghana. Bulletin of the British Museum (Natural History), Botany 11: 215-289.

LOW, A.B. \& REBELO, A.G. (eds) 1996. Vegetation of South Africa. Lesotho and Swaziland. Department of Environmental Affairs \& Tourism, Pretoria

PATON, J.A. 1973. Taxonomic studies in the genus Fossombronia Raddi. Journal of Bryology 7: 243-252.

PEROLD, S.M. 1997a. Studies in the liverwort genus Fossombronia (Metzgeriales) from southern Africa. 1. Three new species from Northern Province, Gauteng and Mpumalanga. Bothalia 27 $17-27$

PEROLD, S.M. 1997b. Studies in the liverwort genus Fossombronia (Metzgeriales) from southern Africa. 2. An amendment to three species from Western Cape, described by S.W. Arnell. Bothalia 27: $29-38$.

PEROLD, S.M. 1997c. Studies in the liverwort genus Fossombronia (Metzgeriales) from southern Africa. 4. A re-examination of $F$ crispa, F. leucoxantha and F. tumida. Bothalia 27: 105-115.

PEROLD, S.M. 1999. Studies in the liverwort genus Fossombronia (Metzgeriales) from southern Africa. 8. F. elsieae and F. spinosa, two new Western Cape species with spinose spores. Bothalia 29: $25-33$.

RUTHERFORD, M.C. 1997. Categorization of biomes. In R.M. Cowling. D.M. Richardson \& S.M. Pierce, Vegetation of southern Africa. Cambridge University Press, Cambridge

SCHUSTER, R.M. 1992. The Hepaticae and Anthocerotae of North America 5: 416. Field Museum of Natural History, Chicago.

SCOTT, G.A.M. \& PIKE, D.C. 1988. A new species of Fossombronia from Australia. Beiheft zur Nova Hedwigia 90: 109-112.

SIM, T.R. 1926. The Bryophyta of South Africa. Transactions of the Royal Society of South Africa 20: 35 